\begin{tabular}{rr} 
Phinisi Integration Review \\
Vol. 2, No.1, Februari 2019 Hal 100-113 \\
Website: $\underline{\text { http://ojs.unm.ac.id/pir }}$ \\
p-ISSN: 2614-2325 dan e-ISSN: 2614-2317 \\
\hline
\end{tabular}

\title{
Pembelajaran Ilmu Pengetahuan Sosial (Studi Integrasi Nilai - Nilai Karakter) Pada Peserta Didik Sekolah Dasar Negeri Sudirman II Makassar
}

\author{
Nurul Istiqamah ${ }^{(1)}$ \\ Universitas Negeri Makassar \\ email: nn84649@gmail.com
}

\begin{abstract}
Abstrak. Penelitian ini bertujuan untuk mengetahui (1) Deskripsi pengintegrasian nilainilai karakter peserta didik dalam pembelajaran IPS di kelas IV/V SDN Sudirman II Makassar, (2) Bentuk penilaian nilai-nilai karakter peserta didik dalam pembelajaran IPS di kelas IV/V SDN Sudirman II Makassar, (3) Faktor yang mempengaruhi pengintegrasian nilai-nilai karakter dalam pembelajaran IPS di kelas IV/V SDN Sudirman II Makassar. Jenis penelitian yang digunakan adalah deskriptif kualitatif. Dalam pengumpulan data, peneliti bertindak sebagai instrumen penelitian. Data yang diperoleh melalui dua sumber yaitu informan dan dokumen. Teknik pengumpulan data dilakukan melalui observasi, wawancara, penilaian proses belajar dan dokumentasi. Pengabsahan data di lakukan dengan perpanjang pengamatan (prolonged engagement), meningkatkan ketekunan (persistent observation), dan triangulasi (peer debriefing). Hasil penelitian mengungkapkan bahwa: (1) Pengintegrasian nilai-nilai karakter dalam pembelajaran IPS di lakukan beberapa tahap pertama, pada kegiatan awal adalah membudayakan berdoa sebelum belajar. Kedua, membahas materi pelajaran sesuai dengan perangkat pembelajaran silabus dan RPP berdasarkan kurikulum 2013 yang di integrasikan nilainilai karakter kedalam pembelajaran IPS. Ketiga, guru memotivasi murid untuk lebih giat belajar, kemudian guru menutup pelajaran dengan membaca do'a. (2) Faktor yang mempengaruhi pengintegrasian nila-nilai karakter adalah karena Adanya paradigma yang sama antara kepala sekolah dan guru tentang pengintegrasian nilai-nilai karakter peserta didik terhadap pembelajaran IPS..
\end{abstract}

Kata Kunci: Nilai - nilai karakter; Pembelajaran IPS.

Abstract. This study aims to determine (1) the description of integration of character
values of students in IPS (social science) learning in grade IV / V at SDN Sudirman II
Makassar, (2) the form of assessment of character values of students in IPS in grade IV /
V at SDN Sudirman II Makassar, and (3) the factor influences the integration of character
values in IPS learning in grade IV/V at SDN Sudirman II Makassar. The study employed
descriptive qualitative. In collecting the data, the researchers was conducted by extending
the observation (prolonged engagement), increasing perseverance (persistent
observation), and triangulation (peer debriefing). The results of the study revealed that:
(1) the integration of character values in IPS learning was counducted in several stages:
first, the preliminary activity is cultivating praying before learning: Second, discussing
learning material aligned with the syllabus and RPP based on the 2013 curriculum which
integrates character values in IPS learning: Third, the teacher motivated students to study
diligently, and then last the teacher ended the learning by praying. (2) the factor 
influences the integration of character values is there is similar paradigm between the principal and teachers on the integration of character values of students on IPS learning.

Keywords: Character value; IPS learning.

c) (7) (8) Ini adalah artikel dengan akses terbuka dibawah licenci CC BY-NC-4.0 (https://creativecommons.org/licenses/by-nc/4.0/ ).

\section{PENDAHULUAN}

Kemajuan suatu bangsa terletak pada karakter yang dimiliki bangsa tersebut. Walaupun hanya tersirat, pembentukan karakter bangsa telah diamanatkan dalam pembukaan UUD 1945 alinea ke-empat, yaitu mencerdaskan kehidupan bangsa. Amanat tersebut dipertegas dalam UUD 1945 pasal 31 ayat 3 (amandemen), yakni pemerintah mengusahakan dan menyelenggarakan satu sistem pendidikan nasional, yang meningkatkan keimanan dan ketakwaan serta akhlak mulia dalam rangka mencerdaskan kehidupan bangsa.

Untuk menjalankan amanat itu, maka dalam UU No. 20 tahun 2003 tentang Sistem Pendidikan Nasional (UU Sisdiknas) pasal 3 ditetapkan fungsi dan tujuan pendidikan nasional, yaitu mengembangkan kemampuan dan membentuk watak serta peradaban bangsa yang bermartabat dalam rangka mencerdaskan kehidupan bangsa, bertujuan untuk berkembangnya potensi murid agar menjadi manusia yang beriman dan bertakwa kepada Tuhan Yang Maha Esa, berakhlak mulia, sehat, berilmu, cakap, kreatif, mandiri, dan menjadi warga negara yang demokratis serta bertanggung jawab.

Persoalan karakter menjadi bahan pemikiran sekaligus keprihatinan bersama karena negara ini dikatakan sedang menderita krisis karakter. Krisis ini ditandai dengan maraknya tindakan kriminal, seperti tawuran antar pelajar, meningkatnya pergaulan bebas, maraknya angka kekerasan anak-anak dan remaja, yang seringkali menjurus pada tindak kekerasan yang meresahkan masyarakat, korupsi yang mewabah dan merambah pada semua sektor kehidupan masyarakat, bahkan pembunuhan. Fenomena tersebut jelas telah mencoreng citra pelajar dan lembaga pendidikan, karena banyak orang berpandangan bahwa kondisi demikian berawal dari apa yang dihasilkan oleh dunia pendidikan.
Atas kondisi demikian, semua pihak sepakat mengatasi persoalan kemerosotan dalam dimensi karakter ini. Sebenarnya, persoalan karakter atau moral tidak sepenuhnya terabaikan oleh lembaga pendidikan. Akan tetapi, fenomena-fenomena yang terjadi menunjukkan bahwa ada kegagalan pada institusi pendidikan dalam menumbuhkan manusia Indonesia yang berkarakter dan berakhlak mulia.

Sementara itu, mata pelajaran pendidikan agama dan pendidikan kewarganegaraan yang diharapkan berkontribusi dalam hal pembentukan karakter, tampaknya lebih mengajarkan pada dasar-dasar agama, serta hak dan kewajiban warga negara sementara akhlak atau kandungan nilai-nilai kebaikan belum sepenuhnya disampaikan, akibatnya murid hanya tahu agama dan tahu aturan tapi tidak diinternalisasi. Karena itu tidaklah mengherankan jika dijumpai inkonsistensi antara apa yang diajarkan di sekolah dan apa yang diterapkan anak di luar sekolah (Supriatna, 2010; Megawangi, 2004:80).

Salah satu upaya yang dapat dilakukan ialah dengan mengembangkan kurikulum.Terkait dengan diberlakukannya Kurikulum Satuan Pendidikan ada beberapa faktor yang menjadi alasan dalam mengembangkan kurikulum, seperti tantangan masa depan dan berbagai fenomena negatif yang terjadi di masyarakat. Tantangan masa depan dimaksudkan bahwa peserta didik harus dipersiapkan dengan ilmu pengetahuan dan teknologi, serta keterampilan yang mumpuni sebagai bekal menggapai kesuksesan di masa depan.

Menanggapi masalah karakter bangsa yang merisaukan itu, dan ketidakberhasilan Pendidikan Agama dan IPS, kementerian pendidikan nasional merespon dengan mencanangkan pendidikan karakter pada lembaga pendidikan formal melalui integrasi 
nilai kedalam pembelajaran setiap mata pelajaran (Kemendiknas, 2010b;9).

$$
\text { Pembelajaran IPS sesungguhnya }
$$

memiliki keterkaitan dengan upaya pengembangan karakter bangsa. Pembelajaran IPS secara jelas memiliki nilai-nilai yang sangat dekat dengan pembentukan karakter murid. Gambaran integrasi nilai-nilai karakter dalam pembelajaran IPS dapat diketahui dari nilainilai karakter yang direkomendasikan kementerian pendidikan nasional. Dari 18 nilai karakter, 11 diantaranya terkait dan dapat diintegrasikan dengan pembelajaran IPS di SD (Kemendiknas, 2010:10-19;37-38).

Melalui pembelajaran IPS terintegrasi nilai karakter diharapkan murid dapat membangun pengetahuannya melalui cara kerja ilmiah, bekerjasama dalam kelompok, belajar berinteraksi dan berkomunikasi, bersikap ilmiah serta berperilaku sesuai dengan nilainilai yang hidup dan berkembang di tengah masyarakat.

Masalahnya adalah hasil survei awal yang dilakukan peneliti kondisi faktual di lapangan SDN Sudirman II Makassar masih terlihat kecenderungan sebagian besar orang tua menyerahkan sepenuhnya pendidikan karakter pada sekolah sehingga tujuan yang akan dicapai belum seperti yang diharapkan. Dan melihat fenomena yang terjadi di lingkungan sekolah SDN Sudirman II Makassar masih terlihat peserta didik yang terlambat hadir disekolah, masih terdapat peserta didik yang kurang aktif dalam kegiatan kelompok, masih terdapat peserta didik yang tidak mandiri, dan kurang menjaga lingkungan kelas. Sementara itu, sejak digulirkannya kebijakan pendidikan karakter tahun 2010 oleh Kementerian Pendidikan Nasional, hingga saat ini belum diperoleh suatu model pembelajaran yang terintegrasi nilai karakter yang dapat dijadikan acuan model bagi guru, termasuk beberapa sekolah yang telah dijadikan sebagai "sekolah piloting" (Kemendiknas, 2011:13-62). Model penerapan pembelajaran berbasis karakter yang ditawarkan masih bersifat umum, belum berupa petunjuk praktis yang berkaitan langsung dan khusus dengan mata pelajaran tertentu

\section{Rumusan Masalah}

1. Bagaimana upaya guru dalam pengintegrasian nilai-nilai karakter peserta didik dalam pembelajaran IPS di Kelas IV/V SDN Sudirman II Kota Makassar?
2. Bagaimana bentuk penilaian nilai-nilai karakter peserta didik dalam pembelajaran IPS di IV/V SDN Sudirman II Kota Makassar?

3. Faktor-faktor apa saja yang mempengaruhi pengintegrasian nilai-nilai karakter peserta didik dalam pembelajaran IPS di Kelas IV/V SDN Sudirman II Kota Makassar?

\section{Tujuan Penelitian}

1. Untuk mengetahui upaya guru dalam pengintegrasian nilai-nilai karakter peserta didik dalam pembelajaran IPS di Kelas IV/V SDN Sudirman II Kota Makassar.

2. Untuk mengetahui bentuk penilaian nilainilai karakter peserta didik dalam pembelajaran IPS di IV/V SDN Sudirman II Kota Makassar.

3. Untuk mengetahui Faktor-faktor apa saja yang mempengaruhi pengintegrasian nilai-nilai karakter peserta didik dalam pembelajaran IPS di Kelas IV/V SDN Sudirman II Kota Makassar

\section{Konsep Nilai Karakter}

Istilah nilai karakter terdapat dua kata yaitu nilai dan karakter. Untuk mengetahui definisi nilai karakter, penulis terlebih dahulu mengemukakan definisi nilai dan karakter. Istilah nilai adalah suatu jenis kepercayaan, yang letaknya berpusat pada sistem kepercayaan seseorang, tentang bagaimana seseorang sepatutnya dalam melakukan sesuatu, atau tentang apa yang berharga dan yang tidak berharga untuk dicapai (Djahiri,1978:107). Gordon Allfort seorang ahli psikologi kepribadian sebagaimana di kutif oleh Mulyana (2004:9) nilai adalah keyakinan yang membuat seseorang bertindak atas dasar pilihannya. Allfort menempatkan keyakinan pada posisi yang lebih tinggi, ketimbang hasrat, motif, sikap, keinginan dan kebutuhan.

Dari beberapa pengertian tentang nilai di atas, dapat disimpulkan bahwa nilai adalah merupakan rujukan untuk bertindak. Nilai merupakan standar untuk mempertimbangkan dan meraih perilaku tentang baik dan tidak baik dilakukan.

Secara bahasa karakter berasal dari bahasa latin "kharakter", "kharassein", "kharax", dalam bahasa inggris: character dan Indonesia "karakter", Yunani character, dari charassein yang berarti membuat tajam, 
membuat dalam. Dalam kamus poerwadarminta, karakter diartikan sebagai tabiat, watak, sifatsifat kejiwaan, akhlak atau budi pekerti yang membedakan seseorang dengan yang lain. Nama dari jumlah seluruh ciri pribadi yang meliputi hal-hal seperti perilaku, kebiasaan, kesukaan, ketidaksukaan, kemampuan, kecenderungan, potensi, nilai-nilai, dan pola-pola pemikiran.

Menurut (Hornby \& Parnwell, 2012: 49) karakter adalah kualitas mental atau moral, kekuatan moral, nama atau reputasi. Hermawan Kertajaya (2010: 3) mendefinisikan karakter adalah "ciri khas" yang dimiliki oleh suatu benda atau individu. Karakter sebagaimana didefinisikan oleh Ratna Megawangi (2004:108) ,mengandung tiga unsur pokok, yaitu mengetahui kebaikan (knowing the good), mencintai kebaikan (loving/feeling the good), dan melakukan kebaikan (doing/action the good). Dalam pendidikan karakter, kebaikan itu sering kali dirangkum dalam sederet sifat-sifat baik. Dengan demikian, maka nilai karakter adalah sesuatu nilai yang dapat dilaksanakan karena pertimbangan perilaku baik atau tidak baik dilakukan. Upaya ini juga memberi jalan untuk menghargai persepsi dan nilai-nilai pribadi yang ditampilkan di sekolah. Fokus nilai-nilai karakter adalah pada tujuan-tujuan etika, tetapi praktiknya meliputi penguatan kecakapan-kecakapan yang penting yang mencakup perkembangan sosial murid.

\section{Butir-Butir Nilai Karakter}

\section{Nilai-nilai Universal}

Nilai-nilai universal di antaranya adalah nilai kebenaran, kejujuran, kebajikan, kearifan, dan kasih sayang. Nilai universal ini dimiliki oleh semua agama, sedangkan nilai yang dicetuskan oleh UNESCO (Rohmat Mulyana, 1993:38) meliputi dua gagasan yang saling berseberangan, yaitu nilai standar yang secara material terukur dan nilai abstrak yang sulit di ukur yang berupa keadilan, kejujuran, kebebasan, kedamaian, dan persamaan.

Menurut Suyanto (2008:39), ada Sembilan pilar karakter yang berasal dari nilainilai luhur universal manusia, yaitu: (1) cinta Tuhan dan segenap ciptaan-Nya, kemandirian dan tanggung jawab, kejujuran/amanah, (4) hormat dan santun, (5) dermawan, suka tolong menolong dan gotong royong/kerja sama, (6) percaya diri dan pekerja keras, (7) kepemimpinan dan keadilan, (8) baik dan rendah hati, dan (9) toleransi, kedamaian, dan kesatuan.

Menurut Richard Eyre \& Linda (1995: 31) nilai yang benar dan di terima secara universal adalah nilai yang menghasilkan suatu perilaku dan perilaku itu berdampak positif baik bagi yang menjalankan maupun orang lain. Inilah prinsip yang memungkinkan tercapainya ketentraman atau tercegahnya kerugian atau kesusahan. Ini sesuatu yang membuat orang lain senang atau tercegahnya orang lain sakit hati.

Lebih lanjut Richard (1995:42) menjelaskan bahwa nilai adalah suatu kualitas yang dibedakan menurut:

a. Kemampuannya untuk berlipat ganda atau bertambah meskipun sering diberikan kepada orang lain.

b. Kenyataan atau (hukum) bahwa makin banyak nilai diberikan kepada orang lain, makin banyak pula nilai serupa yang dikembalikan dan diterima dari orang lain.

Indonesia Heritage Foundation (IHF: 2003) merumuskan Sembilan karakter dasar yang menjadi tujuan pendidikan karakter. Kesembilan karakter tersebut yaitu (1) Cinta kepada Allah dan semesta beserta isinya, (2) Tanggung jawab, disiplin dan mandiri, (3) Jujur, (4) Hormat dan santun, (5) Kasih sayang, peduli dan kerja sama, (6) Percaya diri, kreatif, kerja keras dan pantang menyerah, (7) Keadilan dan kepemimpinan, (8) Baik dan rendah hati, (9) Toleransi, cinta damai dan persatuan.

Kemudian Ari Ginanjar Agustan dengan teori ESQ menyodorkan pemikiran bahwa setiap karakter positif sesungguhnya akan merujuk kepada sifat-sifat mulia Allah, yaitu alAsmah al-Husna. Sifat-sifat dan nama-nama mulia Tuhan inilah sumber inspirasi setiap karakter positif yang dirumuskan oleh siapapun. Dari sekian banyak karakter yang bisa diteladani dari nama-nama Allah itu, Ari merangkumnya dalam tujuh karakter dasar, yaitu jujur, tanggung Jawab, disiplin, Visioner, adil, Peduli lingkungan dan kerja sama. Richard (1995:43) mengelompokkan nilai-nilai universal kedalam dua kategori, yaitu nilai nurani dan nilai memberi.

\section{Nilai-nilai Sektoral}

Yang dimaksud nilai-nilai sektoral adalah nilai-nilai yang menjadi jati diri bangsa dan telah disepakati bersama oleh bangsa tersebut. Nilai-nilai dijadikan sebagai dasar dan 
landasan pendidikan dan pembentukan karakter. Menurut Murli Manohar Joshi (2002:43) pendidikan pada hakikatnya didasarkan pada definisi pendidikan yang berorientasi pada nilai karena sesungguhnya pendidikan merupakan subset suatu pengaturan kultur secara luas dan kultur itu terdiri dari penanaman kemampuan dan pelatihan pancaindra yang berhubungan dengan etika, estetika, kebenaran dan keindahan. Disamping itu kultur juga dapat dipengaruhi oleh pendidikan dan pengajaran, baik mengenai fisik jasmani maupun mental rohani. Sehubungan dengan hal itu, lebih lanjut Machasin (2005:44) mengemukakan hal-hal sebagai berikut. Nilai kewarganegaraan dalam konteks Amerika ada delapan nilai pokok, yakni: (1) hormat, yakni sikap menghargai dan perasaan dihargai orang lain; (2) cinta, yakni mencintai dan dicintai; (3) kejujuran, yakni ketulusan hati dalan menjalin hubungan dengan sesama warga masyarakat; (4) keadilan, dalam pengertian tidak membeda-bedakan perlakuan kepada semua warga; (5) kemurahan hati, yaitu kesediaan unuk memberikan bantuan kepada setiap warga yang memerlukan bantuan; (6) kerja keras, (7) toleransi, yakni sikap menahan diri terhadap perbedaan, sepanjang tidak mengganggu kehidupan bersama; dan (8) kebebasan.

Sementara Character Counts di Amerika (Majid Abdul \& Andayani Dian 2012:43) mengidentifikasikan bahwa karakterkarakter yang menjadi pilar yaitu dapat dipercaya, rasa hormat dan perhatian, tanggung jawab, jujur, peduli, kewarganegaraan, ketulusan, berani, tekun, dan integritas.

Tiap nilai dimulai dengan sikap yang menunjukkan siapa kita atau sutu tindakan memberi, kemudian mewujudkan dalam perbuatan yang juga menampilkan sikap, pembawaan, kualitas, serta bakat. Selanjutnya memberi dan menerima menjadi dua hal yang saling mengisi, saling mendukung, dan saling memperkuat. Menunjukkan siapa kita dan tindakan member bukan hanya menguji nilainilai kita, tetapi juga suatu cara untuk mengajarkan dan menularkan semua itu kepada orang lain.

Dari beberapa nilai pembentuk karakter yang telah diuraikan diatas, namun pendidikan dapat menentukan prioritas pengembangannya untuk melanjutkan nilai-nilai prakondisi yang telah dikembangkan. Nilai-nilai sebaiknya tidak diajarkan tetapi ditangkap. Hal ini menunjukkan bahwa nilai hakikatnya sudah ada. Dengan meminjam istilah Max Scheler, nilai itu ditemukan dan tidak diciptakan, nilai itu dirasakan dan tidak dipikirkan. Nilai membutuhkan pemahaman, nilai mendahului pengalaman, nilai merupakan pusat moralitas yang bersifat hierarkis, dan nilai bersifat mutlak dan apriori.

3. Nilai-nilai Individual

Nilai-nilai individual nilai dipilih, diterima, ditemukan, dihayati, dan diwujudkan dalam sikap dan perbuatan riil setiap individu manusia. Nilai individu ini merupakan corak dari ciri khusus masing-masing dan mengjadi karakter baginya. Nilai karakter individual ini akan diklaim menjadi nilai karakter bangsa jika nilai karakter terwujud dalam perilaku sosial, kolektif sebagai contoh tindak kekerasan massal, perilaku sosial yang merugikan dan sebagainya. Oleh karena itu, bangsa Indonesia memiliki peluang yang sangat besar untuk menjadi bangsa yang maju, adil, makmur, berdaulat, dan bermartabat. Salah satu aspek yang dapat dilakukan untuk mempersiapkan karakter sumber daya manusia yang kuat adalah melalui pendidikan. Pendidikan merupakan upaya yang terencana dalam proses pembimbingan dan pembelajaran bagi individu agar berkembang dan tumbuh menjadi manusia yang mandiri, bertanggung jawab, kreatif, berilmu, sehat dan berakhlak mulia, yang memiliki moralitas tinggi sangat dituntut untuk dibentuk atau dibangun.

\section{Nilai-Nilai Karakter dalam Pembelajaran IPS}

IPS adalah mata pelajaran yang mempelajari tentang kehidupan manusia dalam berbagai dimensi ruang dan waktu serta berbagai aktivitas kehidupannya. Mata pelajaran IPS bertujuan untuk menghasilkan warga negara yang religius, jujur, demokratis, kreatif, kritis, senang membaca, memiliki kemampuan belajar, rasa ingin tahu, peduli dengan lingkungan sosial dan fisik, berkontribusi terhadap pengembangan kehidupan sosial dan budaya, serta berkomunikasi secara produktif.

Ruang lingkup IPS terdiri atas pengetahuan, keterampilan, nilai dan sikap yang dikembangkan dari masyarakat dan disiplin ilmu sosial. Penguasaan keempat konten ini dilakukan dalam proses belajar yang terintegrasi melalui proses kajian terhadap konten pengetahuan. 
Materi IPS mencakup kehidupan manusia dalam: (1) tempat dan lingkungan, (2) waktu perubahan dan keberlanjutan, (3) organisasi dan sistem sosial, (4) organisasi dan nilai budaya, (5) kehidupan dan sistem ekonomi, dan (6) komunikasi dan teknologi. Pengemasan materi IPS disesuaikan dengan jenjang pendidikan.

IPS merupakan mata pelajaran yang memadukan konsep-konsep dasar dari berbagai ilmu sosial yang disusun melalui pendekatan pendidikan dan psikologis serta kelayakan dan kebermaknaannya bagi murid dalam kehidupannya. Dengan memberikan sumbangan berupa konsep-konsep ilmu yang diubah sebagai "pengetahuan" yang berkaitan dengan kehidupan sosial yang harus dipelajari murid. Oleh karena itu dalam rangka pendidikan karakter ada banyak nilai karakter yang memungkingkan ditanamkan melalui pembelajaran IPS.

Dalam buku pengembangan Budaya dan Karakter Bangsa. Pedoman Sekolah (Kemendiknas, 2010:47-48) tentang peta nilai pendidikan budaya dan karakter bangsa berdasarkan mata pelajaran, teridentifikasi 11 nilai karakter yang memiliki keterkaitan antara mata pelajaran IPS pada jenjang SD. Nilai- nilai karakter yang dimaksudkan di atas dapat dilihat dalam Tabel berikut:

\begin{tabular}{|c|c|c|}
\hline No. & $\begin{array}{l}\text { Nilai } \\
\text { karakter- } \\
\text { terkait IPS- } \\
\text { SD } \\
\end{array}$ & $\begin{array}{lr}\text { Nilai } & \text { karakter } \\
\text { untuk } & \text { satuan } \\
\text { pendidikan } & \end{array}$ \\
\hline 1. & $\overline{\text { Religius }}$ & Religius \\
\hline 2. & Toleransi & Jujur \\
\hline 3. & Disiplin & Toleransi \\
\hline 4. & Kreatif & Disiplin \\
\hline 5. & Demokratis & Kerja keras \\
\hline 6. & $\begin{array}{l}\text { Rasa ingin } \\
\text { tahu }\end{array}$ & Kreatif \\
\hline 7. & $\begin{array}{l}\text { Semangat } \\
\text { kebangsaan }\end{array}$ & Mandiri \\
\hline 8. & $\begin{array}{l}\text { Menghargai } \\
\text { prestasi }\end{array}$ & Demokratis \\
\hline 9. & Bersahabat & Rasa Ingin Tahu \\
\hline 10. & $\begin{array}{l}\text { Senang } \\
\text { membaca }\end{array}$ & $\begin{array}{l}\text { Semangat } \\
\text { kebangsaan }\end{array}$ \\
\hline
\end{tabular}

\begin{tabular}{|c|c|c|}
\hline No. & $\begin{array}{l}\text { Nilai } \\
\text { karakter- } \\
\text { terkait IPS- } \\
\text { SD }\end{array}$ & $\begin{array}{lr}\text { Nilai } & \text { karakter } \\
\text { untuk } & \text { satuan } \\
\text { pendidikan } & \end{array}$ \\
\hline 11. & $\begin{array}{l}\text { Peduli } \\
\text { lingkungan }\end{array}$ & Cinta Tanah Air \\
\hline 12. & & Menghargai prestasi \\
\hline 13. & & $\begin{array}{l}\text { Bersahabat/ } \\
\text { komunikatif }\end{array}$ \\
\hline 14. & & Cinta Damai \\
\hline 15. & & Gemar Membaca \\
\hline 16. & & Peduli Lingkungan \\
\hline 17. & & Peduli sosial \\
\hline 18. & & Tanggung Jawab \\
\hline
\end{tabular}

Nilai-nilai karakter sebagaimana yang tertera di dalam tabel menunjukkan bahwa dari 18 nilai karakter yang dianjurkan untuk dikembangkan pada setiap pendidikan, 11 diantaranya yang terkait dengan pembelajaran IPS. Tujuan-tujuan tersebut mengharuskan pembelajaran IPS mengintegrasikan nilai-nilai untuk mengembangkan karakter warga negara yang baik.

\section{Poses Pembelajaran Ilmu Pengetahuan Sosial}

Pelaksanaan pembelajaran Ilmu Pengetahuan Sosial setiap hari dilakukan dengan menggunakan tiga tahapan yaitu kegiatan awal, inti dan penutup.

\section{a. Kegiatan Awal}

Kegiatan ini dilakukan terutama untuk menyiapkan peserta didik secara psikis dan fisik untuk mengikuti proses pembelajaran; memberi motivasi belajar peserta didik secara kontekstual sesuai manfaat dan aplikasi materi ajar dalam kehidupan sehari-hari, dengan memberikan contoh dan perbandingan lokal, nasional, dan internasional; mengajukan pertanyaan-pertanyaan yang mengaitkan pengetahuan sebelumnya dengan materi yang akan dipelajari; menjelaskan tujuan pembelajaran atau kompetensi dasar yang akan dicapai; dan menyampaikan cakupan materi dan penjelasan uraian kegiatan sesuai silabus.

\section{b. Kegiatan inti}

Kegiatan inti difokuskan pada kegiatankegiatan yang bertujuan untuk pengembangan sikap, pengetahuan dan keterampilan. Dalam rangka pengembangan Sikap, maka seluruh aktivitas pembelajaran berorientasi pada tahapan 
kompetensi yang mendorong peserta didik untuk melakukan aktivitas melalui proses afeksi yang dimulai dari menerima, menjalankan,menghargai, menghayati, hingga mengamalkan.

\section{c. Kegiatan Penutup}

Sifat dari kegiatan penutup adalah untuk menenangkan dan melakukan refleksi dalam rangka evaluasi. Evaluasi yang dilakukan mengkhususkan pada seluruh rangkaian aktivitas pembelajaran dan hasil-hasil yang diperoleh dan yang selanjutnya secara bersama menemukan manfaat langsung maupun tidak langsung dari hasil pembelajaran yang telah berlangsung.

Kegiatan penutup juga dimaksudkan untuk memberikan umpan balik terhadap proses dan hasil pembelajaran; melakukan kegiatan tindak lanjut dalam bentuk pemberian tugas, baik tugas individual maupun kelompok; dan menginformasikan rencana kegiatan pembelajaran untuk pertemuan berikutnya.

Beberapa contoh kegiatan akhir/penutup yang dapat dilakukan adalah menyimpulkan/ mengungkapkan hasil pembelajaran yang telah dilakukan, pesan-pesan moral, musik/apresiasi musik/bernyanyi.

\section{METODE PENELITIAN}

\section{Jenis , Lokasi dan Waktu Penelitian}

Jenis penelitian yang digunakan peneliti adalah penelitian jenis deskriptif. Penelitian deskriptif (Descriptive Research), yaitu penelitian yang menggambarkan atau melukiskan situasi tertentu berdasarkan data yang diperoleh secara terperinci sesuai permasalahan yang ditetapkan dalam penelitian ini, (Bungin, 2010: 68).

Selanjutnya penelitian ini merupakan penelitian kualitatif, menurut Bogdan dan Taylor metode penelitian kualitatif adalah prosedur penelitian yang menghasilkan data deskripsi berupa kata-kata tertulis atau lisan dari orang-orang dan perilaku yang dapat diamati, dan dapat juga berupa angka-angka serta penjelasan yang lebih rinci tentang integrasi nilai-nilai karakter. Pendekatan ini diarahkan pada latar dan individu tersebut secara holistik (utuh). (Moleong, 2010: 4).

Lokasi penelitian ini adalah SDN Sudirman II Makassar. Pemilihan ini bukan di maksudkan untuk mencari kelemahan akan tetapi untuk mengetahui dan mencoba mengaplikasikan bagaimana gambaran Integrasi nilai-nilai karakter dalam pembelajaran IPS di Kelas IV/V SDN Sudirman II Makassar.

Penelitian ini dilaksanakan di SDN Sudirman II Makassar. Pelaksanaan penelitian pada tanggal 19 September 2018 sampai dengan 18 Oktober 2018 .

\section{Fokus Penelitian}

Fokus penelitian tentang Integrasi nilainilai karakter dapat dijabarkan sebagai berikut:

1. Pengintegrasian nilai-nilai karakter peserta didik di kelas IV/V dalam pembelajaran IPS .

2. Bentuk penilaian nilai-nilai karakter peserta didik di Kelas IV/V dalam pembelajaran IPS.

3. Faktor yang mempengaruhi pengintegrasian nilai-nilai karakter peserta didik di kelas IV/V dalam pembelajaran IPS.

\section{Deskripsi Fokus}

Untuk menghindari salah penafsiran, maka dikemukakan deskripsi fokus dari penelitian ini sebagai berikut:

1. Pengintegrasian nilai-nilai karakter peserta didik dimaksudkan untuk pengembangan nilai-nilai karakter peserta didik kearah pendewasaan agar memiliki akhlak yang lebih baik yang dapat diwujudkan dalam tingkah lakunya, seperti kedisiplinan, sopan santun, cara berpakaian, cara bergaul, percaya diri dan bertanggung jawab. Dalam penerapan nilai-nilai karakter menekankan pada pembelajaran IPS melalui planning guru dalam mengemas pembelajaran karakter berupa (RPP), proses pembelajaran guru dalam kegiatan belajar mengajar di kelas/di luar kelas dan evaluasi guru dalam melihat perkembangan karakter anak dalam proses pembelajaran.

2. Bentuk penilaian yang diberikan dikembangkan dalam pembelajaran IPS dengan landasan nilai-nilai karakter yang termuat dalam isi silabus dan RPP kurikulum 2013 , pemilihan dan penentuan materi disesuaikan dengan tujuan dan indikator nilai karakter yang telah dirumuskan dan ditetapkan.

3. Faktor yang mempengaruhi pengintegrasian nilai-nilai karakter 
peserta didik dalam pembelajaran IPS di kelas IV/VSDN Sudirman II Makassar antara lain : (a) Adanya paradigma yang sama antara kepala sekolah dan guru tentang pengintegrasian nilai-nilai karakter peserta didik terhadap pembelajaran Ilmu Pengetahuan Sosial.Salah satu bentuk dukungan kepala sekolah dalam pengintegrasian nilai-nilai karakter peserta didik dalam pembelajaran Ilmu Pengetahuan Sosial yaitu membuat kebijakan dan peraturan yang dituangkan dalam bentuk tata tertib.(b) Adanya kerjasama antara guru dan orang tua dalam upaya membentuk karakter peserta didik, terutama dalam pengintegrasian nilai-nilai karakter dalam proses pembelajaran. Keluaraga merupakan lingkungan terdekat dari setiap individu, utamanya bagi seorang anak. Pengetahuan, pemahaman, dan interaksi yang mereka dapatkan pertama kali adalah dari lingkungan keluarga, sekaligus seiring waktu yang akan mengiringi perkembangan mereka. Ketika orang tua membentuk karakter anaknya sejak dini baik itu berupa sikap, emosianal dan lain-lain dan akan menjadi sebuah kebiasaan seorang anak yang akan mereka bawah di lingkungan sekolah dan masyarakat sehingga orang tua memiliki peran besar dalam pembentukan karakter anak-anak mereka. Disekolah guru juga mempunyai peran penting dalam membentuk nilai-nilai karakter yang ada pada diri peserta didik terutama dalam proses pembelajaran agar menjadi anak yang berguna bagi orang tua, agama, nusa dan bangsa.

\section{Subjek Penelitian}

a. Guru, dari guru yang mengajar dan terlibat langsung dalam penerapan integrasi nilai-nilai karakter diperoleh informasi tentang pembelajaran IPS. Pertimbangan utama dalam upaya penerapan integrasi nilai-nilai karakter di SD Inpres Bertingkat Mamajang I salah-satu penggerak utama dalam upaya penerapan integrasi nilai-nilai karakter di SD tersebut. b. Peserta didik, dari peserta didik untuk mendapatkan informasi tentang bagaimana motivasi dan integrasi nilainilai karakter dalam proses pembelajaran IPS di kelas IV/V di SDN Sudirman II Makassar.

\section{Instrumen Penelitian}
a. Lembar Observasi
b. Lembar Wawancara
c. Lembar Penilaian proses belajar
d. Dokumentasi

\section{Teknik Analisis Data}

a. Reduksi data (Data Reduction) melakukan analisis data dengan cara merumuskan, memilih hal-hal pokok, menfokuskan pada hal-hal penting, dan membuat kategori, sehingga memberikan gambaram agar yang jelas serta mempermudah peneliti.

b. Penyajian data (Display Data) mengorganisasikan data, membuat ke dalam pola, membuat uraian singkat bagan, hubungan antara kategori, langkah-langkah yang dilakukan adalah; (a) data yang telah diseleksi diinternalisasikan, dan direlevansikan dengan data etik, (b) informasi yang diperoleh dari wawancara di interprestasikan untuk memberikan gambaran mendeskrifsikan fokus-fokus masalah.

c. Conclusion Drawing/Verivication. Penarikan kesimpulan setelah menyajikan data, peneliti akan menarik sebuah kesimpulan untuk menjawab rumusan masalah, dan memberikan saran-saran berdasarkan hasil penelitian, dan kesimpulam yang diambil.

\section{Teknik Keabsahan Data}

a. Validitas internal (credibility), yaitu ukuran kebenaran data yang dikumpulkan, yang menggambarkan kecocokan konsep peneliti dengan hasil penelitian.

b. Validitas eksternal (keteralihan /transferability), pembuktian hasil penelitian apakah bisa digeralisasikan pada setting sosial yang berbeda tetapi mempunyai karakteristik yang sama. 
c. Kebergantungan(dependability/reliabilita $s$ ), di mana hasil penelitian merupakan refresentasi dari rangkaian kegiatan pencarian data yang dapat ditelusuri jejaknya. Oleh karena itu, audit komisi pembimbing atas proses penelitian, mulai dari penentuan masalah, memasuki lapangan, menentukan sumber data, serta penarikan kesimpulan merupakan ukuran reliabilitas proses penelitian.

d. Kepastian/objektivitas(confirmability) dilakukan bersamaan dengan dependability, untuk menguji keterkaitan hasil dan proses penelitian.

\section{HASIL DAN PEMBAHASAN}

\section{Hasil Penelitian}

\section{a. Deskripsi pengintegrasian nilai-nilai karakter dalam pembelajaran IPS di kelas IV/V SDN Sudirman II Makassar.}

\section{Kelas IV}

\section{a. Kegiatan Awal}

Berdasarkan hasil observasi peneliti pada proses pembelajarn IPS di kelas IV pada kegiatan awal guru mengawali tindakan dengan mengucapkan salam dan memimpin doa sebelum memulai pelajaran, serta mengabsen kehadiran peserta didik. Kemudian guru memberikan motivasi dengan pertanyaanpertanyaan kepada peserta didik tentang sumber energi dalam kehidupan kita. Setelah itu, guru menyampaikan tujuan pembelajaran yang ingin dicapai dalam proses pembelajaran nantinya. Kegiatan awal dalam pembelajaran sering pula di sebut dengan pra intruksional. Fungsi kegiatan awal pembelajaran adalah untuk menciptakan awal pembelajaran yang efektif yang memungkinkan peserta didik dapat mengikuti proses pembelajaran yang baik. Adapun nilai-nilai yang terintegrasi adalah nilai religius, disiplin, rasa ingin tahu, semangat kebangsaan.

\section{b. Kegiatan Inti}

Berdasarkan hasil observasi peneliti pada proses pembelajarn IPS di kelas IV pada kegiatan inti murid dibagi dalam beberapa kelompok setiap kelompok terdiri atas peserta didik secara heterogenkemudian semua peserta didik diperintahkan untuk membuka buku bahan ajar dan peserta didik mengamati teks visual yang ada didalam buku, kemudian guru menanyakan gambar-gambar apa saja yang kamu amati, setiap kelompok mendiskusikannya, kemudian setiap kelompok akan menyampaikan jawabanya kepada kelompok sebelahnya.setelah peserta didik melakukan diskusi dalam kelompok.Selanjutnya guru membahas satu per satu gambar yang ada didepan kelas. Guru menujuk peserta didik untuk menyampaikan jawabanya.

Secara individual peserta didk akan menulis gagasan pokok dari gambar yang telah diamatinya dan Peserta didik akan menukar jawabanya kepada teman sebelahnya.Sebagai pengantar untuk materi pemanfaatan matahari, guru membawa saru jenis tumbuhan dan memperlihatkannya kepada peserta didik, kemudian guru memintan peserta didik untuk mengamati tumbuhan tersebut dengan teliti dan peserta didik juga diminta untuk mengamati cuaca di pagi/siang hari dari kaca jendela kelas.Guru meminta peserta didik menjawab pertanyaan yang diajukan guru tentang apa yang mereka amati tadi dan guru menujuk salah satu peserta didk yang mengankan tangannya untuk menjawab pertanyaan yang diajukan.

Guru bersama-sama denga peserta didik mendiskusikan jawaban secara klasikal, guru memberikan penguatan kepada peserta didik dari hasil diskusi.Peserta didk kemudian mengamati gambar tentang peran matahari bagi kehidupan di Bumi yang terdapat dalam buku paket. Guru mengingatkan pada pesrta didik agar mengamati dengan teliti setaip detail gambar matahari tersebut. kemudian Guru meminta perta didik untuk menjawab pertanyaan berdasarkan gambar yang ada. Guru juga meminta peserta didik untuk mengilustrasikan tentang manfaat lain dari matahari selain yang tertera pada gambar yang ada di buku. Adapun nilai yang terintegrasi adalah nilai toleransi, kreatif, rasa ingin tahu, semangat kebangsaan, menghargai prestasi, bersahabat, senang membaca.

\section{c. Kegiatan Akhir}

Pada tahap proses pembelajarn IPS di kelas IV pada kegiatan akhir adalah guru mengulas kembali kegiatan yang sudah dilakukan dan meminta siswa melakukan refleksi dengan cara menjawab pertanyaan yang diajukan dan memberikan pesan moral pada peserta didik. Adapun nilai-nilai karakter yang terintegrasi adalah nilai menghargai prestasi dan toleransi. 


\section{Kelas V}

a. kegiatan Awal

Berdasarkan hasil observasi peneliti pada proses pembelajarn IPS di kelas V pada kegiatan awal guru mengawali tindakan dengan mengucapkan salam dan menanyakan kabar dan mengecek kehadiran siswa. Kelas dilanjutkan dengan berdoa yang dipimpin oleh salah satu peserta didik siswa yang diminta memimpin do'a adala peserta didik yang datang paling awal (Menghargai kedisplinan peserta didik). Peserta didik diingatkan untuk selalu untuk mengutamakan sikap disiplin dan manfaatnya bagi tercapainya cita-cita. Kemudian guru bersama peserta didik menyanyikan lagu Garuda Pancasila atau lagu nasional lainnya. Guru memberikan penguatan tentang pentingnya menanamkan semangat Nasionalisme pada peserta didik. Guru selalu melakukan pembiasaan membaca/ menulis/ mendengarkan/ berbicara selama 15-20 menit non pelajaran seperti cerita inspirasi dan motivasi. Adapun nilai-nilai yang terintegrasi adalah religius, disiplin, semangat kebangsaan, cinta tanah air, gemar membaca.

b. Kegiatan inti

Berdasarkan hasil observasi peneliti pada proses pembelajarn IPS di kelas V pada kegiatan inti peserta didik diminta menggali informasi dari bacaan yang disajikan, bacaan teks ditujukan untuk memberika stimulus diskusi tentang gambaran interaksi manusia dengan lingkungannya dan keragaman dalam masyarakat (IPS dipadukan dengan PPKN). Dengan bimbingan guru, peserta didik mengidentifikasikan proses-proses yang terkait dengan pengadaan sumber makanana dalam bacaan. Kemudian peserta didik mendiskusikan proses dari awal sumber makanan tersebut berupa tanaman sampai makanan tetsebut siap dimakan. Guru memberikan pertanyaanpertanyaaan pancingan berupa proses apa yang terjadi dan bagaimana lingkungan sosialnya. Dari jawaban-jawaban peserta didik guru memberikan penjelasan tentang makna dari interaksi manusia, contoh-contohnya dan dampaknya bagi manusia. Kegiatan ini digunakan agar peserta didik dapat memahami ilmu pengetahuan sosial (IPS). Guru meminta siswa untuk mengamati lingkungan sekitar mereka dan mengidentifikasikan interaksi manusia.

Kegiatan ini dapat digunakan sebagai alat ukur untuk melihat pemahaman dan keterampilan peserta didik tentang KD IPS dan PPKN. Guru berharap dalam kegiatan ini dapat membangun sikap kemandirian dan tanggung jawab dalam menyelesaikan penugasan pengetahuan tentang interaksi manusia dan keterampilan dalam laporannya, serta pengetahuan tentang keragaman dalam masyarakat dan keterampilan menyajikan hasil pengamatannya. Adapun nilainilai karakter yang terintegrasi adalah nilai toleransi, kreatif, rasa ingin tahu, semangat kebangsaan, menghargai prestasi, bersahabat, senang membaca.

\section{c. Kegiatan Akhir}

Pada tahap proses pembelajarn IPS di kelas $\mathrm{V}$ pada kegiatan akhir adalahpeserta didik mampu mengemukakan hasil belajara hari ini, guru mengulas kembali kegiatan yang sudah dilakukan dan menyimpulkan pembelajaran. Kemudian peserta didik diberikan kesempatan untuk bertanya atau menambahkan informasi dari peserta didik lainnya. Dan guru memberika penugasan dirumah (untuk mengoptimalkan kerja sama, peserta didik dapat berbagi peran dan tugas dengan orang tua). Dan kegiatan akhir salam dan do'a pentup yang dipimpin oleh salah satu peserta didik. Adapun nilai-nilai karakter yang terintegrasi adalah nilai religious, rasa ingin tahu, toleransi.

\section{Bentuk penilaian nilai-nilai karakter dalam pembelajaran IPS di SDN Sudirman II Makassar.}

Berdasarkan pengamatan dilapangan dalam penerapan penilaian nilai-nilai karakter dalam pembelajaran IPS di kelas IV/V SDN Sudirman II Makassar, hasil wawancara penulis dengan Nurlia, S.Pd guru kelas IV mengatakan:

Bentuk penilaian nilai-nilai karakter yang dilakukan guru kelas IV dalam pembelajaranIPS adalahdidasarkan pada indikator yang telah ditentukan yaitu indikator dengan berusaha memahami setiap materi pelajaran, dan juga penilaian nilai-nilai karakter yang 
sesuai dengan kurikulum 2013.(Guru kelas IV, 22 September 2018)

Dari pernyataan diatas dapat disimpulkan bahwa bentuk penilaian nilai-nilai karakter yang dilakukan guru kelas IV/V dalam pembelajaran IPS adalah didasarkan pada indikator yang telah ditentukan yaitu indikator untuk kelas IV adalah mandiri, rasa ingin tahu, kreatif. Dan untuk kelas V yaitu nilai toleransi, rasa ingin tahu, kreatif. Teknik penilaian nilainilai karakter dapat digunakan untuk menilai ketercapaian perilaku karakter peserta didik. Terkait dengan bentuk instrumen penilaian nilainilai karakter dalam pembelajaran IPS di SDN Sudirman II Makassar.

\section{Faktor yang mempengaruhi nilai-nilai karakter pada peserta didik dalam pembelajaran IPS di Kelas IV/V SDN Sudirman II Makassar}

a)Adanya paradigma yang sama antara kepala sekolah dan guru tentang pengintegrasian nilainilai karakter peserta didik terhadap pembelajaran Ilmu Pengetahuan Sosial. Salah satu bentuk dukungan kepala sekolah dalam pengintegrasian nilai-nilai karakter peserta didik dalam pembelajaran Ilmu Pengetahuan Sosial yaitu membuat kebijakan dan peraturan yang dituangkan dalam bentuk tata tertib. (b) Adanya kerjasama antara guru dan orang tua dalam upaya membentuk karakter peserta didik, terutama dalam pengintegrasian nilai-nilai karakter dalam proses pembelajaran. Ketika orang tua membentuk karakter anaknya sejak dini baik itu berupa sikap, emosianal dan lainlain dan akan menjadi sebuah kebiasaan yang akan mereka bawah di lingkungan msyarakat dan sekolah. Disekolah guru juga mempunyai peran penting dalam membentuk nilai-nilai karakter yang ada pada diri peserta didik

\section{Pembahasan}

Dari hasil penelitian yang telah dipaparkan diatas, dalam pembahasan hasil penelitian ini akan diuraikan secara berturutturut sebagai berikut:

\section{Pembahasan pengintegrasian nilai-nilai karakter peserta didik dalam pembelajaran IPS di kelas IV SD Inpres Bertingkat Mamajang I Kota Makassar}

Gambaran pengintegrasian nilai-nilai karakter dalam pembelajaran IPS dikelas IV
SDN Sudirman II Makassar di lakukan beberapa tahapan. (a)Pertama, guru mengawali tindakan dengan mengucapkan salam dan memimpin doa sebelum memulai pelajaran, serta mengabsen kehadiran peserta didik. Kemudian guru memberikan motivasi dengan pertanyaanpertanyaan kepada peserta didik tentang sumber energi dalam kehidupan kita. Setelah itu, guru menyampaikan tujuan pembelajaran yang ingin dicapai dalam proses pembelajaran nantinya. Disini guru menegaskan betapa pentingnya nilai religius pada peserta didik Kedua, pada kegiatan inti pengintegrasian nilai-nilai karakter peserta didik dalam pembelajaran IPS di kelas IV adalah memberikan tujuan atau garis besar materi dan kemampuan yang akan dipelajari dan menyampaikan kegiatan belajar yang akan ditempuh peserta didik serta membahas materi atau menyajikan bahan pelajaran sesuai dengan perangkat pembelajaran silabus dan rencana pelaksanaan pembelajaran (RPP) berdasarkan kurikulum 2013 yang di integrasikan nilai-nilai karakter kedalam pembelajaran IPS.Ketiga, Pada kegiatan Akhirguru mengulas kembali kegiatan yang sudah dilakukan dan meminta siswa melakukan refleksi dengan cara menjawab pertanyaan yang diajukan dan memberikan pesan moral pada peserta didik. Gambaran pengintegrasian nilai-nilai karakter dalam pembelajaran IPS di kelas V SDN Sudirman II Makassar di lakukan beberapa tahapan. (a) pertama, guru mengawali tindakan dengan mengucapkan salam dan menanyakan kabar dan mengecek kehadiran siswa. Kelas dilanjutkan dengan berdoa yang dipimpin oleh salah satu peserta. Peserta didik diingatkan untuk selalu untuk mengutamakan sikap disiplin dan manfaatnya bagi tercapainya cita-cita. Kemudian guru bersama peserta didik menyanyikan lagu lagu nasional. Guru memberikan penguatan tentang pentingnya menanamkan semangat Nasionalisme pada peserta didik. Guru selalu melakukan pembiasaan membaca/ menulis/ mendengarkan/ berbicara selama 15-20 menit non pelajaran seperti cerita inspirasi dan motivasi. sebelum membaca buku, guru menjelaskan tujuan kegiatan literal seperti menberika pertanyaan apa judul buku dll. Kedua, pada kegiatan inti pengintegrasian nilai-nilai karakter peserta didik dalam pembelajaran IPS di kelas $\mathrm{V}$ adalah memberikan tujuan atau garis besar materi dan kemampuan yang akan dipelajari dan menyampaikan kegiatan belajar yang akan ditempuh peserta didik serta membahas materi 
atau menyajikan bahan pelajaran sesuai dengan perangkat pembelajaran silabus dan rencana pelaksanaan pembelajaran (RPP) berdasarkan kurikulum 2013 yang di integrasikan nilai-nilai karakter kedalam pembelajaran IPS. Ketiga, peserta didik mampu mengemukakan hasil belajara hari ini, guru mengulas kembali kegiatan yang sudah dilakukan dan menyimpulkan pembelajaran. Kemudian peserta didik diberikan kesempatan untuk bertanya atau menambahkan informasi dari peserta didik lainnya. Dan guru memberika penugasan dirumah (untuk mengoptimalkan kerja sama, peserta didik dapat berbagi peran dan tugas dengan orang tua). Dan kegiatan akhir salam dan do'a pentup yang dipimpin oleh salah satu peserta didik.

\section{Bentuk penilaian nilai-nilai karakter peserta didik dalam pembelajaran IPS di kelas IV/V SDN Sudirman II Makassar \\ Bentuk penilaian nilai-nilai karakter peserta} didik dalam pembelajaran IPS di SDN Sudirman II Makassar adalah didasarkan pada indikator yang telah ditentukan yaitu indikator untuk kelas IV yaitu nilai mandiri, rasa ingin tahu dan kreatif dan nilai karakter untuk kelas V yaitu nilai toleransi, rasa ingin tahu, kreatif, menghargai prestasi . Bentuk instrumen penilaian yang digunakan untuk observasi dalam pembelajaran IPS adalah pedoman observasi yang berupa daftar cek penilaian (rating scale) yang disertai rubrik. Daftar cek digunakan untuk mengamati ada tidaknya suatu sikap atau perilaku.Pedoman observasi secara umum memuat pernyataan sikap atau perilaku yang diamati dan hasil pengamatan sikap atau perilaku sesuai kenyataan.Pernyataan memuat sikap atau perilaku yang positif atau negatif sesuai indikator penjabaran sikap dalam standar kompetensi dan kompetensi dasar.

\section{Faktor yang mempengaruhi pengintegrasian nilai-nilai karakter peserta didik dalam pembelajaran IPS di kelas IV/V SDN Sudirman II Makassar.}

Faktor yang mempengaruhi pengintegrasian nilai-nilai karakter peserta didik dalam pembelajaran IPS di kelas IV/VSDN Sudirman II Makassar antara lain :

(a) Adanya paradigma yang sama antara kepala sekolah dan guru tentang pengintegrasian nilainilai karakter peserta didik terhadap pembelajaran Ilmu Pengetahuan Sosial.Salah satu bentuk dukungan kepala sekolah dalam pengintegrasian nilai-nilai karakter peserta didik dalam pembelajaran Ilmu Pengetahuan Sosial yaitu membuat kebijakan dan peraturan yang dituangkan dalam bentuk tata tertib.(b) Adanya kerjasama antara guru dan orang tua dalam upaya membentuk karakter peserta didik, terutama dalam pengintegrasian nilai-nilai karakter dalam proses pembelajaran. Keluaraga merupakan lingkungan terdekat dari setiap individu, utamanya bagi seorang anak. Pengetahuan, pemahaman, dan interaksi yang mereka dapatkan pertama kali adalah dari lingkungan keluarga, sekaligus seiring waktu yang akan mengiringi perkembangan mereka. Ketika orang tua membentuk karakter anaknya sejak dini baik itu berupa sikap, emosianal dan lain-lain dan akan menjadi sebuah kebiasaan seorang anak yang akan mereka bawah di lingkungan sekolah dan masyarakat sehingga orang tua memiliki peran besar dalam pembentukan karakter anak-anak mereka. Disekolah guru juga mempunyai peran penting dalam membentuk nilai-nilai karakter yang ada pada diri peserta didik terutama dalam proses pembelajaran agar menjadi anak yang berguna bagi orang tua, agama, nusa dan bangsa.

\section{SIMPULAN DAN SARAN}

\section{Kesimpulan}

Berdasarkan rumusan masalah, hasil penelitian dan pembahasan ini tentang Integrasi nilai-nilai karakter dalam pembelajaran IPS di kelas IV SD Inpres Bertingkat Mamajang I Kota Makassar disimpulkan bahwa:

a. Gambaran penerapan nilai-nilai karakter peserta didik dalam pembelajaran IPS di SDN Sudirman II Makassar dilakukan beberapa tahapan pertama, pada kegiatan awal pengintegrasikan nilai-nilai karakter dalam pembelajaran IPS adalah membudayakan berdoa sebelum belajar. Keteladanan ini diterapkan guna memberikan pemahaman kepada peserta didik betapa pentingnya nilai religius. Kedua, pada kegiatan inti pengintegrasian nilai-nilai karakter peserta didik dalam pembelajaran IPS adalah memberikan tujuan atau garis besar materi dan kemampuan yang akan dipelajari dan menyampaikan 
kegiatan belajar yang akan ditempuh peserta didik serta membahas materi atau menyajikan bahan pelajaran sesuai dengan perangkat pembelajaran silabus dan rencana pelaksanaan pembelajaran (RPP) berdasarkan kurikulum 2013yang di integrasikan nilai-nilai karakter kedalam pembelajaran IPS. Ketiga, guru memberikan kesempatan pada peserta didik untuk bertanya tentang materi yang telah dipelajari jika masih ada yang belum dipahami dan guru tidak lupa memberikan soal tes evaluasi kepada setiap murid. Setelah itu guru memotivasi murid untuk lebih giat belajar, kemudian guru menutup pelajaran dengan membaca do'a.

b. Bentuk penilaian nilai-nilai karakter peserta didikdalam pembelajaran IPSdi kelas IV/V di SDN Sudirman II Makassar adalah didasarkan pada indikator yang telah ditentukan yaitu indikator untuk nilai rasa ingin tahu, disiplin, bertanggung jawab, dan peduli lingkungan.Bentuk instrumen penilaian yang digunakan untuk observasi dalam pembelajaran IPS adalah pedoman observasi yang berupa daftar cek atau skala penilaian (rating scale) yang disertai rubrik. Daftar cek digunakan untuk mengamati ada tidaknya suatu sikap atau perilaku. Sedangkan skala penilaian menentukan posisi sikap atau perilaku siswa dalam suatu rentangan sikap. Pedoman observasi secara umum memuat pernyataan sikap atau perilaku yang diamati dan hasil pengamatan sikap atau perilaku sesuai kenyataan. Pernyataan memuat sikap atau perilaku yang positif atau negatif sesuai indikator penjabaran sikap dalam standar kompetensi dan kompetensi dasar.

c. Faktor yang mempengaruhi pengintegrasian nilai-nilai karakter peserta didikdalam pembelajaran IPS di kelas IV/V SDN Sudirman II Makassar adalah (a)Adanya paradigma yang sama antara kepala sekolah dan guru tentang pengintegrasian nilai-nilai karakter peserta didik terhadap pembelajaran Ilmu Pengetahuan Sosial. Salah satu bentuk dukungan kepala sekolah dalam pengintegrasian nilai-nilai karakter peserta didik dalam pembelajaran Ilmu Pengetahuan Sosial yaitu membuat kebijakan dan peraturan yang dituangkan dalam bentuk tata tertib. (b) Adanya kerjasama antara guru dan orang tua dalam upaya membentuk karakter peserta didik, terutama dalam pengintegrasian nilai-nilai karakter dalam proses pembelajaran. Ketika orang tua membentuk karakter anaknya sejak dini baik itu berupa sikap, emosianal dan lain-lain dan akan menjadi sebuah kebiasaan yang akan mereka bawah di lingkungan msyarakat dan sekolah. Disekolah guru juga mempunyai peran penting dalam membentuk nilai-nilai karakter yang ada pada diri peserta didik

\section{Saran}

Berdasarkan kesimpulan, dikemukakan beberapa saran sebagai berikut:

a. Kepada Kepala Sekolah SDN Sudirman II Makassar, agar pengintegrasian nilai-nilai karakter dalam pembelajaran IPS yang telah berjalan dipertahankan serta ditingkatkan dan aspek yang belum terlaksana agar semakin disempurnakan.

b. Kepada guru SDN Sudirman II Makassar, agar lebih giat menyosialisasikan pengintegrasian nilai-nilai karakter kepada orang tua murid dalam bentuk yang lebih inovatif agar penerapan nilai-nilai karakter dapat lebih optimal. Dan agar lebih giat mengembangkan media pembelajaran nilainilai karakter sehingga penerapan nilai-nilai karakter berjalan lebih efektif.

c. Kepada orang tua/wali peserta didik, hendaknya lebih terlibat aktif dan memberikan perhatian khusus kepada anakanaknya terutama mengenai perkembangan karakter mereka agar menjadi individu yang berakhlak.

\section{DAFTAR RUJUKAN}

Djahiri. 1978. Konsep Nilai karakter Jakarta: Prima Pustaka.

Indonesia Heritage Fondation. 2003. Pendidikan 9 Pilar Karakter. "Membangun Bangsa Berkarakter". Jakarta: Indonesia Heritage Fondation

Joshi, Murli Manohar. 2002. Philosophy of Value Oriented Education Yogyakarta: Pustaka Pelajar.

Kementrian Pendidikan Nasional Badan Penelitian dan Pengembangan Pusat Kurikulum.Bahan Pelatihan Penguatan Metodologi Pembelajaran Berdasarkan Nilai-Nilai Budaya Untuk 
Nurul Istiqamah. Pembelajaran Ilmu Pengetahuan Sosial (Studi Integrasi Nilai - Nilai Karakter) Pada Peserta Didik Sekolah Dasar Negeri Sudirman II Makassar

Membentuk Daya Saing Dan Karakter Bangsa. Pengembangan Pendidikan dan Karakter Bangsa.(Jakarta: Kemendiknas, 2010)

Kemendiknas, 2010.Panduan Pendidikan Karakter di Sekolah Menengah Pertama.Jakarta: Direktorat Jenderal manajemen Pendidikan Dasar dan Menengah; Direktorat Pembinaan Sekolah Menengah Pertama.

Kertajaya, Hermawan. 2010. Pendidikan Karakter Perspektif Islam Bandung: PT Remaja Rosdakarya.

Machasin, 2005.Respons Pesantren terhadap Civic Values Pusat Kajian Dinamika Agama, Budaya dan Masyarakat.Banten dan Tasikmalaya.

Majid, Abdul. Dkk. 2012. Pendidikan Karakter Perspektif Islam. Bandung: PT. Remaja Rosdakarya.

Maksudin, 2013.Pendidikan Karakter NonDikotomik. Yogyakarta: Pustaka Pelajar.

Megawangi, Ratna. Dkk. 2004.Pendidikan Karakter. Jakarta: Indonesia Heritage Fondation.

Moleong, J. Lexy. 2010. Metode Penelitian Kualitataif. Bandung: PT Remaja Rosdakarya.

Mulyana, R. 2004. Mengartikulasikan Pendidikan Nilai. Bandung: Alfabeta.

Mulyana, Rohmat 1993. Mengartikulasikan Pendidikan Nilai Yogyakarta: Pustaka Pelajar.

Muslich, Masnur. 2011. Pendidikan Karakter Menjawab Tantangan Krisis Multidimensional. Jakarta: Bumi Aksara.

Parnwell, Hornby . 2012. Konsep Dasar Pendiddikan Karakter Bandung: PT Remaja Rosdakarya Offset.

Richard. 1995. Butir-butir Nilai Karakter. Bandung: PT Remaja Rosdakarya.
Suyanto. 2008. Urgensi Pendidikan Karakter. Jakarta: Direktorat Jenderal Manajemen pendidikan Dasar dan Menengah. 